\title{
UJI FORMULASI KADAR VITAMIN C TABLET EKSTRAK DAUN JERUK NIPIS (CITRUS AURANTIFOLIA)
}

\section{Subagja dan Rahma Nafi'ah}

Sekolah Tinggi Farmasi (STF) YPIB Cirebon

Email: subagja8@gmail.com dan rahmasudjono@gmail.com

\begin{abstract}
Abstrak
Tanaman Jeruk Nipis (Citrus aurantifolia) merupakan tanaman dengan tinggi mencapai 5 meter, dimana merupakan tanaman tropis. Kandungan Jeruk Nipis salah satunya vitamin $C$. Penelitian ini bertujuan untuk mengetahui pada formula manakah tablet ekstrak daun Jeruk Nipis (Citrus aurantifolia) memenuhi persyaratan uji kadar vitamin $C$, dan tablet yang dihasilkan diuji evaluasi tablet meliputi: organoleptik, kekerasan, kerapuhan, waktu hancur, keseragaman ukuran, keseragaman bobot, disolusi, dan kadar vitamin C. Metode dalam penelitian ini menggunakan jenis penelitian eksperimen. Teknik analisis data yang digunakan yaitu Uji Linearitas dan Analisis Regresi Linear Sederhana. Hasil penelitian menunjukan bahwa tablet ekstrak daun Jeruk Nipis (Citrus aurantifolia) tidak memenuhi persyaratan tablet, dan tablet ekstrak daun Jeruk Nipis (Citrus aurantifolia) kadar $200 \mathrm{mg}$ per tablet memenuhi persyaratan uji kadar vitamin $C$ sebesar 93,33\%.
\end{abstract}

Kata kunci: Tablet ekstrak daun Jeruk Nipis (Citrus aurantifolia), kadar vitamin C, evaluasi tablet.

\section{Pendahuluan}

Pengaruh era globalisasi di segala bidang, perkembangan teknologi dan industri mengakibatkan perubahan pada perilaku dan gaya hidup masyarakat serta situasi lingkungan, seperti perubahan terhadap pola konsumsi makanan yang serba instan, serta perkembangan dunia teknologi dan komunikasi yang semakin meninggi membuat manusia seakan enggan untuk bergerak dan berolahraga (Subandi, 2017).

Tren global back to nature turut menyebabkan terjadinya peningkatan kesadaran masyarakat akan produksi pangan organik dan obat-obatan berbasis bahan baku alam yang lebih sehat, aman, dan murah. Sekitar $80 \%$ penduduk dunia telah memanfaatkan tumbuhan obat untuk memelihara kesehatan primernya dan perlu diketahui bahwa sekitar $25 \%$ obat modern berasal dari tanaman obat (Dalimartha, 2008).

Jeruk nipis mengandung minyak atsiri, vitamin B1, vitamin C, kalsium, hidrat arang, zat besi, lemak, kalori, protein, air, limonene, linalin asetat, geranil asetat, fellandren, sitrat dan asam sitrat (Suparni., 2012).

Salah satu bentuk sediaan farmasi yang banyak digunakan adalah tablet, karena mempunyai beberapa keuntungan antara lain ketepatan dosis, dapat dikemas secara baik, praktis transportasi, serta mudah pemakaiannya dan stabilitas obat yang baik 
selama penyimpanan (Fatmawaty, 2019). Penelitian dengan judul "Uji Formulasi Kadar Vitamin C Tablet Ekstrak Daun Jeruk Nipis (Citrus aurantifolia)" dilakukan di Laboratorium Farmasetika, Sekolah Tinggi Farmasi (STF) YPIB Cirebon, Jalan Perjuangan Majasem No.7 Kota Cirebon, sedangkan waktu penelitian dilaksanakan pada bulan Oktober 2018 sampai dengan bulan Juni 2019.

Alat yang digunakan: timbangan, maserator, batang pengaduk, kain flanel, cawan porselen, evapoator, mortir dan stamper, pipet tetes, gelas ukur, beaker glass, corong kaca, labu tentukur, oven, spatel, kertas perkamen, spuit, jangka sorong, pencetak tablet single punch, alat evaluasi tablet, spektrofotometer, kuvet, stopwatch.

Bahan yang digunakan: daun Jeruk Nipis, Vitamin C, PVP, Mg Stearat, talk, amilum, laktosa, nipagin, etanol 70\%, aquades, aerosil, $\mathrm{HCl} 0,1 \mathrm{~N}$.

\section{Metode Penelitian}

Penelitian ini merupakan penelitian terhadap formulasi tablet yang dibuat dari ekstrak jeruk nipis. Formulasi tablet yang dibuat menggunakan 3 (tiga) tingkat konsentrasi, yaitu: (a) $50 \mathrm{mg}$ ekstrak daun jeruk nipis per tablet; (b) $100 \mathrm{mg}$ ekstrak daun jeruk nipis per tablet; dan (c) $200 \mathrm{mg}$ ekstrak daun jeruk nipis per tablet. Bobot tablet yang dibuat adalah $600 \mathrm{mg}$.

Evaluasi terhadap sediaan dilakukan pada tahap granulasi dan setelah tablet selesai dicetak. Parameter evaluasi terhadap granul meliputi kecepatan alir, sudut diam, kompresibilitas dan kadar air. Sementara evaluasi terhadap tablet meliputi evaluasi sediaan tablet dan uji disolusi. Parameter evaluasi terhadap tablet meliputi kekerasan, kerapuhan, keseragaman bobot, keseragaman ukuran dan waktu hancur. (Depkes RI, 2015)

\section{Hasil dan Pembahasan}

\section{Hasil pembuatan ekstrak}

Ekstraksi daun Jeruk Nipis (Citrus aurantifolia) dilakukan dengan menggunakan metode maserasi. Serbuk simplisia daun Jeruk Nipis sebanyak 500gram direndam dengan etanol $70 \%$ sebagai penyari sebanyak $3500 \mathrm{ml}$ (7 bagian) dan $1500 \mathrm{ml}$ etanol 70\% (3 bagian) setelah hari ke-5. Hasil meserat pada hari ke-5 sebanyak $2950 \mathrm{ml}$ dan hari ke-7 sebanyak $978 \mathrm{ml}$ sehingga jumlah ekstrak cair sebanyak $3928 \mathrm{ml}$. Ekstrak cair dikentalkan dengan menggunakan evaporator sehingga ekstrak kental yang didapat sebanyak 146,5 gram. Hasil rendemen 29,3\%.

\section{Hasil pembuatan granul}

Pembuatan tablet diawali dengan pembuatan granul terlebih dahulu. Metode yang digunakan adalah metode granulasi basah. Hasilnya didapat X1 sebesar 165,95 gram, X2 sebesar 162,22 gram, dan X3 sebesar 159,63 gram. 


\section{Hasil evaluasi granul}

\section{a. Hasil uji kecepatan alir}

Hasil rata-rata uji kecepatan alir adalah X1 yaitu 8,51 g/detik, X2 sebesar 7,14 g/detik, dan X3 sebesar 7,37 g/detik. Semua hasil uji rata-rata kecepatan alir menunjukkan hasil memenuhi syarat (dengan simpulan baik).

\section{b. Hasil uji sudut diam}

Hasil Rata-Rata Uji Sudut Diam X1 sebesar 27,6 $6^{\circ}$ dengan simpulan baik; X2 sebesar $29,6^{\circ}$ dengan simpulan baik; dan X3 sebesar $31,5^{\circ}$ dengan simpulan cukup.

\section{c. Hasil uji kompresibilitas}

Hasil Rata-Rata Uji Kompresibilitas X1 sebesar 11,4 \% dengan simpulan sangat baik; X2 sebesar 10,2 \% dengan simpulan sangat baik; dan X3 sebesar $12,1 \%$ dengan simpulan sangat baik.

\section{d. Hasil uji kadar air}

Hasil rata-rata uji kadar air X1 sebesar 4,8 \% dengan simpulan tidak memenuhi syarat; $\mathrm{X} 2$ sebesar 4,1\% dengan simpulan tidak memenuhi syarat; dan X3 sebesar 4,2\% dengan simpulan tidak memenuhi syarat.

\section{Hasil evaluasi tablet}

\section{a. Hasil uji kekerasan}

Hasil uji kekerasan $\mathrm{X} 1$ sebesar 4,52 kg dengan simpulan memenuhi syarat; X2 sebesar 4,7 kg dengan simpulan memenuhi syarat; dan X3 sebesar 4,73 kg dengan simpulan memenuhi syarat.

\section{b. Hasil uji kerapuhan}

Hasil uji kerapuhan $\mathrm{X} 1$ sebesar $0,70 \%$ dengan simpulan memenuhi syarat; X2 sebesar 0,78 \% dengan simpulan memenuhi syarat; dan X3 sebesar $0,95 \%$ dengan simpulan memenuhi syarat.

\section{c. Hasil uji keseragaman ukuran}

Hasil uji keseragaman ukuran X1, X2, dan X3 memenuhi persyaratan.

\section{d. Hasil uji keseragaman bobot}

Hasil uji keseragaman bobot menunjukkan X1 dengan rata-rata bobot 0,578 gram; X2 dengan rata-rata bobot 0,577 gram; dan X3 dengan rata-rata bobot 0,58 gram.

\section{e. Hasil uji waktu hancur}

Hasil uji waktu hancur menunjukkan semua sampel uji (X1, X2, dan X3) memenuhi persyaratan uji waktu hancur yaitu dibawah 15 menit.

\section{f. Hasil penetapan kadar vitamin $\mathrm{C}$}

\begin{tabular}{c|c|c|c}
\hline No. & Formula & Absorbansi & Kadar (\%) \\
\hline 1. & X1 & 0,241 & 77,25 \\
\hline 2. & X2 & 0,278 & 88,76 \\
\hline 3. & X3 & 0,295 & 93,33 \\
\hline \multicolumn{3}{l}{ Syarat: Kadar $=90,0 \%-110,0 \%$}
\end{tabular}


Dengan data yang didapatkan hanya formula X3 yang memenuhi persyaratan hal tersebut bisa terjadi karena X3 menggunakan lebih banyak ekstrak daun jeruk nipis sebesar $200 \mathrm{mg}$.

g. Hasil uji disolusi

\begin{tabular}{c|c|c|c}
\hline Waktu & \multicolumn{3}{|c}{ Persentase Kumulatif Vitamin C yang Terlepas (\%) } \\
\hline & $\mathbf{X 1}$ & $\mathbf{X 2}$ & $\mathbf{X 3}$ \\
\hline 5 & 7,74 & 6,84 & 13,68 \\
\hline 10 & 9,9 & 18 & 19,08 \\
\hline 15 & 13,14 & 27,36 & 20,88 \\
\hline 20 & 14,58 & 30,6 & 24,84 \\
\hline 35 & 22,23 & 39,6 & 45,54 \\
\hline 45 & 29,52 & 44,46 & 61,2
\end{tabular}

Dari data tersebut X1 dan X2 tidak memenuhi persyaratan disolusi tablet. Sedangkan X3 memenuhi persyaratan disolusi Q-15\% yaitu dari kuartil sebesar 75 dikurangi 15 yaitu 60, sehingga hasil dari X3 61,2 berada di Q-15\%.

\section{Kesimpulan}

Tablet ekstrak daun Jeruk Nipis (Citrus aurantifolia) tidak memenuhi persyaratan tablet. Tablet ekstrak daun Jeruk Nipis (Citrus aurantifolia) dosis $200 \mathrm{mg}$ per tablet memenuhi persyaratan uji kadar vitamin $\mathrm{C}$ sebesar 93,33\%. 


\section{BIBLIOGRAFI}

Dalimartha, S. (2008). Atlas tumbuhan obat Indonesia (Vol. 2). Niaga Swadaya.

Depkes RI. 2015. Farmakope Indonesia Edisi V. Jakarta: Departemen Kesehatan Republik Indonesia.

Fatmawaty, A., Nisa M., dan Rezki, R. (2019). Teknologi Sediaan Farmasi. Yogyakarta: Penerbit Deepublish.

Subandi, E. (2017). Pengaruh Senam Diabetes Perhadap Penurunan Kadar Gula Darah Pada Pasien Diabetes Mellitus Di UPT Puskesmas Mundu Kabupaten Cirebon Tahun 2017. Syntax Literate; Jurnal Ilmiah Indonesia, 2(7), 53-68.

Suparni., W. (2012). Herbal Nusantara: 1001 Ramuan Tradisional Asli Indonesia. Andi Publisher. 